\title{
SUPERVISI PENDIDIKAN DALAM UPAYA PENINGKATAN PROFESIONALITAS GURU MENDIDIK PESERTA DIDIK DALAM PEMBELAJARAN
}

\author{
Monica Putri Safira \\ monicasafira15@gmail.com
}

\begin{abstract}
ABSTRAK
Pendidikan adalah upaya untuk mengembangkan ilmu pengetahuan, pandangan hidup dan keterampilan individual atau sosial seseorang. Upaya untuk mengembangkan ini dapat dilaksanakan dalam berbagai bentuk, diantaranya adalah pendidikan formal, informal, dan non formal. Penyelenggaraan pendidikan dalam bentuk apapun haruslah sesuai dengan ketentuan dan ketetapan yang telah ditentukan sebelumnya. Kendala yang sering dihadapi dalam penyelenggaraan pendidikan adalah sudah berkurangnya rasa tanggung jawab guru terhadap mendidik karakter anak. Guru saat ini banyak yang mengajar hanya sekadar mengajar, perihal murid paham adalah urusan belakangan. Alasan lain, guru mengajar hanya sebatas tuntutan pekerjaan yang tiap bulan digaji dengan nominal tertentu. Supervisi akademik adalah serangkaian kegiatan membantu guru mengembangkan kemampuannya dalam mengelola proses pembelajaran untuk mencapai tujuan pembelajaran. Upaya peningkatan motivasi guru dilakukan dengan cara mengadakan supervisi pendidikan yang ketat dan objektif lalu memberikan tinjak lanjut berupa reward, sanksi, dan atau pelatihan/penataran yang sesuai dengan kinerja guru tersebut. Hasil supervisi perlu ditindaklanjuti agar memberikan dampak nyata bagi peningkatan profesionalitas guru.
\end{abstract}

Kata kunci: pendidikan, supervisi pendidikan, guru, peserta didik, profesionalitas guru

\section{LATAR BELAKANG}

Pendidikan adalah upaya untuk mengembangkan ilmu pengetahuan, pandangan hidup dan keterampilan individual atau sosial seseorang. Upaya untuk mengembangkan ini dapat dilaksanakan dalam berbagai bentuk, diantaranya adalah pendidikan formal, informal, dan non formal. Pendidikan formal diselenggarakan secara sengaja, terencana dan sistematis serta terarah, pendidikan informal diselenggarakan secara sengaja tapi tidak terencana dan tidak sistematis seperti lingkungan keluarga, sedangkan pendidikan non formal diselenggarakan secara sengaja dan berencana tetapi diluar lingkungan keluarga dan lembaga pendidikan formal (Titik, 2014). 
Menurut Undang-Undang Republik Indonesia Nomor 20 Tahun 2003 Tentang Sistem Pendidikan Nasional, Pasal 3, pendidikan nasional berfungsi mengembangkan kemampuan dan membentuk watar serta peradaban bangsa yang bermartabat dalam rangka mencerdaskan kehidupan bangsa, bertujuan untuk berkembangnya potensi peserta didik agar menjadi manusia yang beriman dan bertakwa kepada Tuhan Yang Maha Esa, berakhlak mulia, sehat, berilmu, cakap, kreatif, mandiri dan menjadi warga negara yang demokratis. Sehingga pendidikan itu sangatlah penting, karena generasi-genera si muda di Indonesia harus memiliki pendidikan yang baik sebagai agen perubahan.

Penyelenggaraan pendidikan dalam bentuk apapun haruslah sesuai dengan ketentuan dan ketetapan yang telah ditentukan sebelumnya. Hanya saja, dalam praktiknya banyak terjadi penyimpangan yang mungkin tidak teramati oleh supervisi pendidikan. Kendala yang sering dihadapi dalam penyelenggaraan pendidikan adalah sudah berkurangnya rasa tanggung jawab guru terhadap mendidik karakter anak. Guru saat ini banyak yang mengajar hanya sekadar mengajar, perihal murid paham adalah urusan belakangan. Alasan lain, guru mengajar hanya sebatas tuntutan pekerjaan yang tiap bulan digaji dengan nominal tertentu. Inilah yang menjadi pokok pembahasan kali ini, mengapa kredibilitas guru saat ini berkurang dan hanya mengajar tanpa mendidik? Padahal, ia telah mendapat gaji rutin (bagi yang berstatus PNS) dalam jumlah yang relatif cukup, terlebih lagi, bagi guru yang sudah lolos sertifikasi, ia telah mendapat tunjangan sertifikasi guru dalam jumlah yang lumayan.

Berdasarkan uraian diatas, rumusan masalah yang diajukan adalah "bagaimana pengaruh supervisi pendidikan terhadap peningkatan kompetensi guru dalam mendidik peserta didik dalam pembelajaran". Tulisan ini bertujuan untuk mengetahui bersarnya pengaruh supervisi pendidikan terhadap peningkatan kompetensi guru dalam mendidik peserta didik dalam pembelajaran.

\section{PEMBAHASAN}

Dalam Undang-Undang Sistem Pendidikan Nasional No 20 Tahun 2003 disebutkan bahwa pendidikan nasional berfungsi untuk mengembangkan serta membentuk watak peradaban bangsa yang bermartabat untuk mewujudkan cita-cita bangsa, yaitu mencerdaskan kehidupan berbangsa serta berupaya untuk mengembangkan potensi serta kemampuan peserta didik dan menjadikan mereka menjadi manusia yang beriman, berakhlak mulia, berilmu cakap, kreatif, mandiri dan menjadi warga Negara yang demokratis serta tanggung jawab. Seluruh lembaga satuan pendidikan di Indonesia tanpa terkecuali memiliki peran penting untuk merealisasikan fungsi pendidikan nasional tersebut. Semua jenjang pendidikan termasuk sekolah Dasar memiliki peranan penting untuk mewujudkan tujuan pendidikan nasional tersebut.

Pendidikan karakter tidak hanya mengajarkan tentang pilihan hal yang benar dan hal yang buruk, tetapi juga menanamkan karakter atau kebiasaan-kebiasaan yang berguna. Dengan pendidikan karakter, peserta didik akan mampu mencapai tiga ranah penting dalam pendidikan. Ranah tersebut 
diantaranya adalah ranah kognitif, yaitu yang bersifat pemahaman dan pengetahuan; ranah afektif, yaitu mampu merasakan nilai yang baik (loving the good/moral feeling); dan ranah psikomotor, yaitu perilaku dan kebiasaan melakukan sesuatu. Pendidikan karakter memiliki tiga fungsi utama. Pertama, membentuk dan mengembangkan potensi siswa agar berpikiran baik, berhati baik, dan berperilaku sesuai dengan falsafah pancasila. Kedua, memperbaiki dan memperkuat peran keluarga, satuan pendidikan, masyarakat, dan pemerintah untuk ikut berpartisipasi dan bertanggung jawab dalam pengembangan potensi warga negara dan pembangunan menuju bangsa yang maju, mandiri, dan sejahtera. Ketiga, memilah budaya bangsa sendiri dan menyaring budaya bangsa lain yang tidak sesuai dengan nilai-nilai budaya bangsa dan karakter bangsa yang bermartabat. Ketiga fungsi tersebut seharusnya dijalankan sebagaimana mestinya (Wulandari \& Kristiawan, 2017).

Pendidikan karakter merupakan gerakan nasional untuk menciptakan sekolah yang membina generasi muda yang beretika, bertanggung jawab, dan peduli. Pendidikan karakter yang baik harus melibatkan pengetahuan yang baik (moral knowing), perasaan yang baik atau loving good (moral feeling) dan perilaku yang baik (moral action). Tanpa ketiga pencapaian tersebut, maka pendidikan karakter tidak dapat dilakukan. Pendidikan karakter adalah penciptaan lingkungan sekolah yang membantu siswa dalam mengembangkan etika, bertanggung jawab terhadap moral dan pengajaranpengajaran yang sesuai dengan nilai-nilai universal (Lestari \& Yusmiono, 2018).

Supervisi akademik adalah serangkaian kegiatan membantu guru mengembangkan kemampuannya dalam mengelola proses pembelajaran untuk mencapai tujuan pembelajaran. Supervisi akademik tidak terlepas dari penilaian kinerja dosen atau instruktur dalam mengelola pembelajaran. Supervisi akademik ini biasanya dilakukan oleh supervisor atau profesional di bidangnya. Refleksi praktis penilaian kinerja guru atau instruktur dalam supervisi akademik adalah bagaimana praktik kinerja guru untuk menjawab pertanyaan-pertanyaan, misalnya apa yang sebenarnya terjadi di dalam kelas?, apa yang sebenarnya dilakukan oleh guru dan siswa di dalam kelas?, aktivitas-aktivitas apa saja di dalam kelas itu yang bermakna bagi guru dan mahasiswa?, apa yang dikerjakan oleh guru untuk mencapai tujuan akademik?, apa kelebihan dan kekurangan guru dan bagaimana cara mengembangkannya dan memperbaikinya?. Informasi mengenai kemampuan guru dalam pembelajaran dapat diperoleh berdasarkan jawaban terhadap pertanyaan-pertanyaan tersebut. Setelah melakukan supervisi pendidikan, hal penting lain yang perlu dilakukan adalah tindak lanjutnya berupa pembuatan program supervisi akademik dan melaksanakannya dengan sebaik mungkin (Rahmat, 2013)

Teknik supervisi individual ada lima macam yaitu:

1. kunjungan kelas,

2. observasi kelas,

3. pertemuan individual, 
4. kunjungan antarkelas, dan

5. menilai diri sendiri.

Observasi kelas adalah mengamati proses pembelajaran secara teliti di kelas. Tujuannya adalah untuk mendapatkan data-data yang bersifat objektif dari aspek-aspek pembelajaran, kesulitankesulitan guru dalam upaya perbaikan pembelajaran.

Secara umum, aspek-aspek yang diobservasi adalah:

1) usaha-usaha dan aktivitas guru-siswa dalam proses pembelajaran,

2) penggunaan media pengajaran,

3) metode yang bervariasi,

4) ketepatan penggunaan media dengan materi,

5) ketepatan penggunaan metode dengan materi, dan

6) reaksi mental para siswa dalam proses belajar mengajar.

(Rahmat, 2013)

Guna peningkatan kualitas pembelajaran yang lebih efektif dapat dilakukan peningkatan kompetensi guru yang dilakukan dengan pelatihan. Pelatihan merupakan meningkatkan pengetahuan dari anggota organisasi untuk melakukan tertentu dan keterampilan untuk tujuan tertentu. Pelatihan harus memiliki dampak secara langsung dan spesifik pada prestasi kerja dan berdasarkan kebutuhan dan budaya organisasi. Ada banyak alasan perlunya pelatihan guru oleh supervisor, diantaranya :

1. peningkatan kepuasan kerja dan semangat

2. peningkatan motivasi guru,

3. peningkatan efisiensi dalam proses

4. yang maksimal,

5. peningkatan kapasitas untuk mengadopsi

6. teknologi dan metode baru,

7. peningkatan inovasi dalam strategi dan

8. meningkatkan citra lembaga.

(Sabandi, 2013)

Adanya guru kurang profesional dalam mengajar akan sangat mengkhawatirkan dunia pendidikan, terutama di sekolah tingkat dasar. Sekolah tingkat dasar merupakan dasar pendidikan yang akan mempengaruhi sifat dan kebiasaan peserta didik selama pembelajaran. Guru-guru memiliki peran penting untuk menanamkan sifat suka peserta didik terhadap belajar. Banyak faktor yang 
menyebabkan guru kurang profesional, seperti kurangnya pemahaman guru terhadap bahan ajar yang akan disampaikan, selain itu juga dipengaruhi oleh kondisi fasilitas sekolah yang kurang kondusif untuk proses belajar mengajar. Untuk itu perlu dilakukan supervisi pendidikan yang dilakukan oleh inspektor yang profesional dibidangnya, untuk mengetahu kekurangan-kekurangan atau kesalahan yang perlu diperbaiki.

Dengan meningkatkan kinerja supervisi pendidikan, sesuai dengan teknik-teknik yang telah dilakukan seperti uraian diatas. Dalam strategi supervisi pendidikan ada enam aspek yang perlu diperhatikan, yaitu tentang apa yang harus dilakukan, mengapa harus dilakukan, siapa yang akan melakukan, berapa lama kegiatan itu dilakukan, serta hasil apa yang hendak diperoleh. Dengan ini, diharapkan kegiatan supervisi untuk mengamati, menilai, dan membina guru dapat memperoleh hasil yang lebih optimal dalam upaya meningkatkan sikap profesional guru. Hasil supervisi perlu ditindaklanjuti untuk memberikan dampak nyata bagi peningkatan profesionalisme guru. Tindak lanjut tersebut dapat berupa penguatan dan penghargaan yang diberikan kepada guru yang telah memenuhi standar, teguran yang bersifat mendidik pada guru yang belum memenuhi standar dan kebijakan serta guru diberi kesempatan untuk mengikuti pelatihan/penataran lebih lanjut.

\section{KESIMPULAN}

Upaya peningkatan motivasi guru dilakukan dengan cara mengadakan supervisi pendidikan yang ketat dan objektif lalu memberikan tinjak lanjut berupa reward, sanksi, dan atau pelatihan/penataran yang sesuai dengan kinerja guru tersebut. Guru adalah suatu profesi yang mulia, dengan tujuan mencerdaskan kehidupan bangsa yang mesti ditunaikan dengan komitmen yang kuat dan kompetensi yang sesuai standar. Komitmen tinggi lahir dari hati yang suci, bersih dan bertanggung jawab serta memiliki kesadaran akan tugasnya. Hal ini dapat mempengaruhi kinerja dan profesionalias guru.

\section{SARAN}

Kepada Dinas Pendidikan, tingkat provinsi maupun daerah, agar menyelenggarakan pembinaan kompetensi Kepala Sekolah, baik sekolah negeri maupun swasta, dalam berbagai bidang secara rutin dan kontinyu. Kepada Kepala Sekolah, hendaknya dapat mengikuti dan mengadakan kegiatan pelatihan dengan pikiran positif, termasuk kegiatan penelitian tindakan sekolah dan aktif melaksanakan tugas sebagaimana mestinya. Kepada Pengurus KKG, agar dapat secara terus menerus melaksanakan tugasnya dalam upaya membantu guru dalam peningkatan potensi diri dan profesionalitasnya. Kepada semua Guru, hendaklah menyadari betapa pentingnya tugas mulianya 
yang bertujuan untuk kehidupan bangsa yang cerdas dan ditunaikan dengan sungguh-sungguh (profesional).

\section{DAFTAR PUSTAKA}

Lestari, N. D., \& Yusmiono, B. A. (2018). (Jurnal Manajemen, Kepemimpinan, dan Supervisi Pendidikan) Volume 3, No. 1, Januari-Juni 2018. (Jurnal Manajemen, Kepemimpinan, Dan Supervisi Pendidikan), 3(1), 114-125.

Rahmat, S. (2013). Supervisi pendidikan. Tadris Jurnal Penelitian Dan Pemikiran Islam, 1(1), 1-18. Retrieved from http://stitmatuban.ac.id/wp-content/uploads/2015/10/TD1.3-SupervisiPendidikan-H.-Sutrisno-Rahmat.pdf

Sabandi, A. (2013). SUPERVISI PENDIDIKAN UNTUK PENGEMBANGAN PROFESIONALITAS GURU BERKELANJUTAN. Jurnal Ilmiah Ilmu Pendidikan, XIII, 1-9.

Titik. (2014). Supervisi Akademik dalam Upaya Peningkatan Motivasi Guru Menyusun Perangkat Persiapan Pembelajaran. Jurnal Penelitian Tindakan Sekolah Dan Kepengawasan, 1(2), 57-62.

Wulandari, Y., \& Kristiawan, M. (2017). Strategi Sekolah Dalam Penguatan Pendidikan Karakter Bagi Siswa Dengan Memaksimalkan Peran Orang Tua. JMKSP (Jurnal Manajemen, Kepemimpinan, Dan Supervisi Pendidikan), 2(2), 290-302. 